IZA DP No. 4287

Circular Migration or Permanent Return:

What Determines Different Forms of Migration?

Florin P. Vadean

Matloob Piracha

July 2009 


\title{
Circular Migration or Permanent Return: What Determines Different Forms of Migration?
}

\author{
Florin P. Vadean \\ University of Kent \\ Matloob Piracha \\ University of Kent \\ and IZA
}

Discussion Paper No. 4287

July 2009

IZA

P.O. Box 7240

53072 Bonn

Germany

Phone: $+49-228-3894-0$

Fax: +49-228-3894-180

E-mail: iza@iza.org

\begin{abstract}
Any opinions expressed here are those of the author(s) and not those of IZA. Research published in this series may include views on policy, but the institute itself takes no institutional policy positions.

The Institute for the Study of Labor (IZA) in Bonn is a local and virtual international research center and a place of communication between science, politics and business. IZA is an independent nonprofit organization supported by Deutsche Post Foundation. The center is associated with the University of Bonn and offers a stimulating research environment through its international network, workshops and conferences, data service, project support, research visits and doctoral program. IZA engages in (i) original and internationally competitive research in all fields of labor economics, (ii) development of policy concepts, and (iii) dissemination of research results and concepts to the interested public.
\end{abstract}

IZA Discussion Papers often represent preliminary work and are circulated to encourage discussion. Citation of such a paper should account for its provisional character. A revised version may be available directly from the author. 


\section{ABSTRACT}

\section{Circular Migration or Permanent Return: What Determines Different Forms of Migration?*}

This paper addresses the following questions: To what extent do the socio-economic characteristics of circular/repeat migrants differ from migrants who return permanently to the home country after their first trip (i.e. return migrants)? and What determines each of these distinctive temporary migration forms? Using Albanian household survey data and both a multinomial logit model and a maximum simulated likelihood (MSL) probit with two sequential selection equations, we find that education, gender, age, geographical location and the return reasons from the first migration trip significantly affect the choice of migration form. Compared to return migrants, circular migrants are more likely to be male, have primary education and originate from rural, less developed areas. Moreover, return migration seems to be determined by family reasons, a failed migration attempt but also the fulfillment of a savings target.

JEL Classification: $\quad$ C35, F22, J61

Keywords: return migration, circular migration, sample selection

Corresponding author:

Matloob Piracha

Department of Economics

University of Kent

Canterbury, Kent CT2 7NP

United Kingdom

E-mail: M.E.Piracha@kent.ac.uk

\footnotetext{
* We would like to thank Artjoms Ivlevs, participants at the $8^{\text {th }}$ Annual GEP Postgraduate Conference and at the $12^{\text {th }}$ IZA European Summer School in Labor Economics for helpful comments on earlier versions of the paper. An earlier version was part of a report for the "Managing Labour Migration to Support Economic Growth" project coordinated by the OECD Development Centre, whose financial support is gratefully acknowledged. The usual disclaimer applies.
} 


\section{Introduction}

Circular migration (i.e. the repeated back and forth movements between the home country and one or more countries of destination) is frequently linked to expectations of mutual gains for migrant sending and receiving countries and migrants and their families. The general idea is that circularity of skilled workers would allow industrialised countries to fill labour market gaps with the simultaneous compensation of possible "brain drain" in developing migrant sending countries, through transfers of know-how and technology. Moreover, circular migration at all skill levels should have a positive effect on sustained remittance flows; these private money transfers being often perceived to make an important contribution to poverty alleviation and investment opportunities in the home country.

While the socio-economic motivations and determinants of temporary migration have been extensively analysed in the literature (e.g. Djajic and Milbourne, 1988; Stark, 1991; Borjas and Bratsberg, 1996; Dustmann 1995, 1997, and 2003; and Mesnard, 2004), most studies focused mainly on the decision of migrants to return to the home country and the amount of time spent abroad, irrespective of the form of temporary migration. ${ }^{1}$ The increased interest in circular migration gives rise, however, to questions about the differences in socioeconomic characteristics between circular/repeat migrants and migrants who return permanently to the home country (usually after the first trip) and the determinants of these distinctive temporary migration forms. Assessing them could be fundamental in understanding the way in which migration can be more effectively managed for the benefit of both sending and receiving countries.

We attempt to fill this gap in the literature by analysing the correlates and determinants of different forms of temporary migration in a systematic way. First, using a multinomial logit model, we analyse the choice of individuals from four alternatives: no migration, long-term/permanent migration, return migration, and circular migration. ${ }^{2}$ Then, using a maximum simulated likelihood (MSL) probit with two sequential selection equations, we investigate the probability of returnees to re-migrate after their first trip, by controlling for sample selection bias into initial migration and return migration. Along with the socioeconomic and regional characteristics, we also take into consideration the effect of own

\footnotetext{
${ }^{1}$ There are a few exceptions. Massey and Espinosa (1997) analyse the re-migration decision of return migrants in Mexico but without taking into account the possible sample selection bias (i.e. return migrants may be a nonrandom selected group of the total population). Constant and Zimmermann (2007) study the topic from the host country perspective. They analyse the frequency of exits and the amount of time spent outside Germany by guest-workers who entered the country before 1984.

${ }^{2}$ In our analysis return migration refers to permanent return to the home country after a single migration episode whereas circular migration refers to multiple (two or more) trips, i.e. back and forth movements between the home country and one or more countries of destination. Temporary migration includes both migration forms.
} 
migration history (e.g. past migration movements, legal vs. illegal residence, success in finding work and return reasons) on the re-migration intentions of returnees, as previous experience is assumed to strongly affect subsequent migration decisions. Our main research questions are: To what extent do the socio-economic characteristics of circular/repeat migrants differ from migrants who return permanently to the home country after their first trip? and, What determines each of these distinctive temporary migration forms?

We aim to answer these questions using data from the Albanian Living Standard Measurement Survey (ALSMS) 2005. This dataset contains a rich set of information on the past trips of return migrants as well as information on both the non-migrant, migrant and temporary migrant population groups, allowing us to conduct a reasonable analysis of the self-selection of individuals into different migration forms. ${ }^{3}$ To our knowledge this is the first study to analyse circular migration in the context of the European East-West migration experience.

Our results show that education, gender, age, geographical location and the return reasons from the first migration trip significantly affect the choice of migration form. Compared to return migrants, circular migrants are more likely to be male, have primary education and originate from rural, less developed areas. Moreover, permanent return after the first trip seems to be determined by family reasons, a failed migration attempt but also the fulfilment of a savings target. The results also confirm the hypothesis that return migration accentuates the negative of selection that generated the initial migration flow (see Borjas and Bratsberg, 1996). Moreover, circular migration seems to further intensify the selection, circular migrants being significantly less skilled compared to returnees.

The remainder of the paper is organised as follows. The next section presents a general framework for analysis. Some background information and stylised facts on the different forms of Albanian migration are presented in section 3. Section 4 presents the econometric specification, while Section 5 discusses the empirical results of the multivariate analysis of the determinants of migration forms. Last section concludes the paper.

\section{Framework for Analysis}

Inherent in the concept of temporary migration is the decision to return to the home country after spending a period of time in the host country. However, the idea of return migration is at odds with the perceived notion of migration which is seen as a strategic choice

\footnotetext{
${ }^{3}$ Datasets from migrant sending countries usually have information only on non-migrants and return migrants, but not on the characteristics of migrants that are abroad, while migrant host country data lack information on the characteristics of the population from which immigrants are selected (i.e. the non migrants).
} 
by individuals to move from a low-wage, high unemployment region/country to the one which has relatively higher wages and employment rates. Since agents make a life-time, utility maximising decision based on perceived net benefits from migration, migrants should intuitively remain abroad until retirement. However, many recent papers have explored the possibility of return migration before the end of the individual's active life cycle (i.e. retirement) and despite persistent income differences between the home and host countries.

Arguments used for explaining the decision to return are, for example, locationspecific preferences (i.e. higher utility for consumption at home), differences in purchasing power between the host and home country currencies, higher returns at home to the human capital accumulated in the host country, or higher returns at home to the capital accumulated abroad in the presence of capital constraints (e.g. Djajic and Milbourne, 1988; Dustmann 1995, 1997, and 2003; and Mesnard, 2004).

Alternatively, return may occur due to a revision of the initial migration decision. For example, a migrant may return as a result of failure in achieving initial migration target (i.e. does not find job or finds a job only at a lower wage than expected; Borjas and Bratsberg, 1996) or because of ranking higher in the income distribution in the home reference group compared to the reference group in the host country (i.e. relative deprivation; Stark, 1991).

The empirical analysis conducted in this paper is based on two decision frameworks. On the one hand, as in Hill (1987), the choice of circular migration can be considered integral to the initial migration decision, i.e. made before the migrant leaves the home country (see Decision Tree 1). Given higher income opportunities abroad and preference for living at home, individual utility is assumed to depend on a time path of residence in the home and host country and is maximised by choosing the optimal amount of time spent abroad as well as the frequency of trips.

\section{Decision Tree 1: Return and re-migration integral to the initial migration decision}

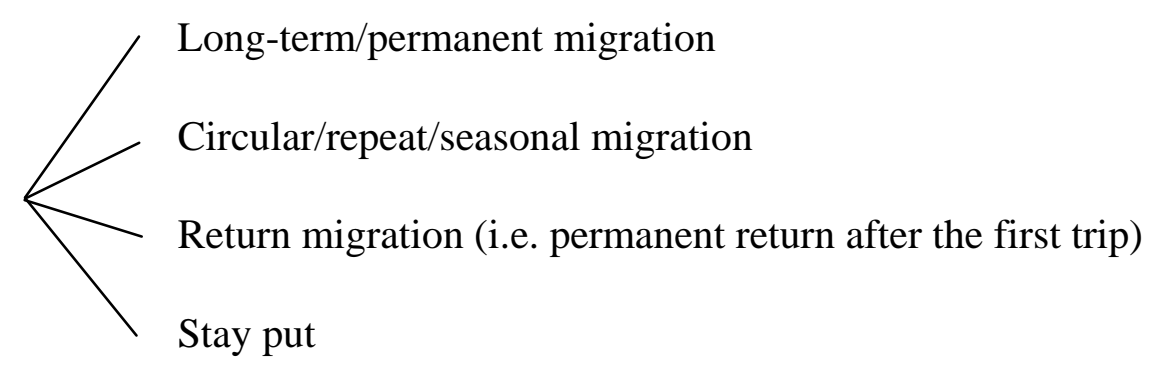

On the other hand, the decision process can be, for example, altered by the presence of uncertainty or imperfect information about the prospects in the destination country (and, 
while abroad, about the prospects in the home country). In this setup, a migrant decides while abroad, based on the realities he faces, whether he should return or not. ${ }^{4}$ However, once back home, there is another layer in the decision process regarding re-migration, perhaps due to problems of re-integration, the failure to find a suitable job or having to acquire more capital for the business started after return. In this case, the decision process would have the following form:

\section{Decision Tree 2: Multiple revisions of the migration decision}

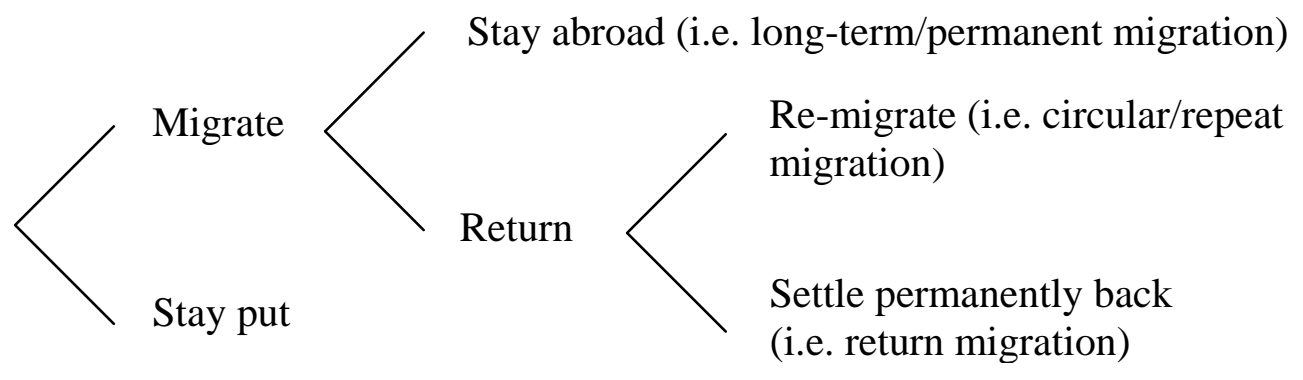

Another complexity of the migration process comes from the character of the migration decision: is it a choice or an outcome? Considering return as endogenous, the migrant decides about the form of migration, the duration of stay abroad and eventually the frequency of trips (Radu and Epstein, 2007). Temporary migration might, however, be induced exogenously by host country policies as well. In recent years, there has been a proliferation of immigrant employment schemes in industrial countries for sectors with jobs avoided by natives, with strong seasonal fluctuations (e.g. farming, road repairs and construction), and in the service industry (e.g. hotels and restaurants). These employment schemes offer a variety of pre- and post-admission conditions and incentives, designed to keep flows temporary (Dayton-Johnson et al., 2007).

Nevertheless, migrants do have the option among different immigration regimes, e.g. those which are more open to permanent migration (i.e. US, Canada, Australia, and New Zealand), those with temporary migration programmes (i.e. West European countries and the Gulf States), and/or those that are more lax with respect to immigration offences (i.e. irregular migration, overstaying of temporary residence permits; e.g. South European countries). Therefore, in the majority of cases the form of migration can be assumed to be a choice.

\footnotetext{
${ }^{4}$ Note that, for the purpose of our analysis, long-term and permanent migration is treated in the same way. Based on this we will use the two words interchangeably throughout the text.
} 


\section{Background and Data}

Precise figures on Albanian migration are difficult to gather due to the potentially high number of non-declared (illegal) migrants. Existing estimates suggest that since 1990 over a million Albanians (i.e. about 30 percent of the population) have either settled or worked for short time periods abroad, which is by far the highest proportion amongst the Central and East European countries (Vullentari, 2007; ETF, 2007). Own estimates based on data from the 2005 Albanian Living Standard Measurement Survey (ALSMS), led to similar figures. Using direct information on the migration history of the individuals surveyed and indirect information on the present migration status and migration history of the spouses and children living outside the household and the siblings of the household head and spouse, we found that in 2005 about 24.6 percent of the Albanian population aged 15 to 64 was either currently migrant (16.5 percent) or had a past migration experience (8.1 percent). In addition, part of the migrants living abroad at the time of the survey will also return and hence the asserted proportion of one third temporary migrants should be seen as a lower bound.

The main reason for migration is for employment purposes. The collapse of the industrial sector in the early transition years, on the one hand, and the absence of a welfare state on the other, has pushed many workers outside the labour market and into poverty. By 2004, around 30 percent of Albanians were estimated to live below the poverty line; half of them in extreme poverty, subsisting on less than US\$ 1 per day (Barjaba, 2004). In face of these harsh realities, many have sought employment abroad, mainly in neighbouring EU countries.

Because of their geographical proximity, the main destination countries are Greece and Italy, hosting almost 80 percent of Albania's migrants in 2005. About 600,000 worked and/or lived in Greece, about 250,000 in Italy, while another approximately 250,000 were scattered among industrialised countries in Western Europe and North America (Vullentari, 2007). The sector of employment and, thus, the form of migration is varying significantly among destinations: seasonal employment in construction, farming and tourism in Greece; temporary employment in manufacturing, construction and services in Italy; and predominantly permanent migration of skilled migrants to Western Europe, the US, and Canada (ETF, 2007; Barjaba, 2004).

The data used for the empirical analysis is from the 2005 Albanian Living Standards Measurement Survey (ALSMS), collected by the Albanian Institute for Statistics (INSTAT) with technical support from the World Bank. The data is based on a survey of 3,640 
households (17,302 individuals) and contains a detailed module on migration. ${ }^{5}$ We drew the information on migrants from two parts of the migration module. The first is on the migration history of the household members present (e.g. country of last migration episode, year of migration, time spent abroad, legal residence abroad, legal work abroad, reasons for returning to Albania, previous migration episodes since turning 15, etc.). The second part provides detailed information on the spouse and/or children that are currently abroad and we added these absent household members to the sample.

Since the focus of the paper is the analysis of the determinants of labour migration movements, we restricted our sample to individuals in the potential labour force (i.e. not enrolled in education, not a housewife/-husband, not retired, not handicapped, and not in military service) and aged 20 to 60. Moreover, in order to select the permanent migrants from our second group, we excluded all migrants that were abroad at the time of the survey for three years or less (i.e. 539 observations). For the purpose of this analysis, our definition for a permanent migrant is, hence, an individual who has spent 37 months or more abroad since the last time he/she left the country. ${ }^{6}$

Given the above screening and after excluding all observations with missing values for the variables included, our sample contains 7,280 individuals: out of which 4,756 (65.3 percent) are non-migrants, 1,430 (19.6 percent) permanent migrants, 536 (7.4 percent) return migrants (i.e. individuals who migrated only once and were back in Albania at the time of the survey), and 558 (7.7 percent) circular migrants (i.e. individuals who migrated more than once in the past and were back in Albania at the time of the survey).

Group mean values of the data described above show that Albanian migration, and in particular temporary migration, is predominantly male (see Table 1). Females represent 35 percent of the permanent migrants, but only 8.2 percent of the return migrants and just 1.4 of the circular migrant group.

Migrants in all groups are on average younger compared to non migrants. In order for migration to be financially rewarding (i.e. additional income from employment abroad to exceed the migration costs) it has to take place early in the active lifetime. Taking into account that migration costs are highest if resettling permanently to another country, it is not surprising that permanent migrants are on average the youngest at time of migration with an average age of 25.1 compared to 29.4 in the case of return migrants.

\footnotetext{
${ }^{5}$ A migrant is defined as a person who migrated abroad for at least one month, for non visits purposes, since turning age 15.

${ }^{6}$ Percentile statistics show that 90 percent of the temporary migrants returned to Albania after spending a maximum of three years abroad during their first migration episode.
} 
Regarding the educational composition of the different groups, permanent and return migrants have the highest secondary education rate: 45.9 and 49.4 percent respectively, compared to 38.9 percent for non-migrants. The most affected during the economic transition were secondary educated workers who lost their jobs following the bankruptcy of uncompetitive state owned factories. Many of them used migration as a strategy to improve their standard of living. Moreover, 55.6 percent of circular migrants have at most primary education (which probably explains also why they are on average younger at their first migration trip than the return migrants). Majority of them are probably small (subsistence) farmers who supplement their income through seasonal work abroad. Tertiary educated are least likely to migrate, mostly because of relatively better job opportunities for this group in Albania. With 12.6 percent, the tertiary education rate of non migrants is about 3 percentage points higher compared to permanent and return migrants and 8.3 percentage points higher compared to circular migrants.

Migrants were significantly more likely to have spoken at least one foreign language in 1990, with the form of migration being related to the language of the destination countries. It seems that permanent migration was driven by the proficiency in English (9.2 percent) and/or Italian (12.3 percent); return migration by the knowledge of Italian (8.6 percent) and/or Greek (7.1 percent); while circular migration by the knowledge of Greek (6.4 percent). The main destination country for circular migrants has been Greece (88.0 percent); for return migrants Greece (74.8 percent) and Italy (16.6 percent), while many permanent migrants have also settled, besides Greece (41.1 percent) and Italy (37.9 percent), in other West European or North American countries (21.0 percent).

In terms of marital status, permanent migrants have the lowest marriage rate in 2005. Nevertheless, at the time they left the country, they had the highest marriage rate (72.3 percent) compared to the other migrant groups (63.2 percent for return and 53.1 percent for circular migrants). Migrating for longer periods without the spouse sets, in many cases, considerable strain on the relationship of a couple, often leading to separation and divorce. On the other hand, the savings accumulated abroad made it easier for temporary (i.e. return and circular) migrants to start up a family after return. Similarly, temporary migrants were significantly more likely to have children at the time of their first migration but they were less likely to migrate with them.

Return migration seems to be more common among members of relatively richer households. Many in this group are target savers originating from middle or upper middle class families who, through migration and investment of the repatriated savings after return, 
significantly improved their economic situation above the Albanian average (see Piracha and Vadean, 2009). Compared to permanent migrants, they might also have decided to return permanently back because of their relatively better social and economic position in Albania (Stark and Taylor, 1991). Contrarily, circular migrants are members of poorer and relatively larger families.

Permanent migrants originate from households with less social connections, which probably means they had lower social and emotional relocation costs. However, they left from communities that have more individuals as current or past migrants. As found in other studies, that could be evidence of the fact that migrant networks and/or the culture of migration in the community are important for the migration decision (see Azzarri and Carletto, 2009).

Geographically, most permanent and return migrants are from urban areas (56.6 percent and 57.6 percent respectively), while circular migrants originate from rural areas (62.8 percent) and regions closer to Greece (i.e. the Central and the Mountain regions). ${ }^{7}$

Regarding the migration history, circular migrants were least likely to have legal residence during their first migration trip (only 23.8 percent of them) but that increased considerably in time to 54.5 percent for the last migration trip. This is certainly due to the large legalisation programs in Greece and Italy after 1999. As for return migrants, they are also quite likely to have migrated illegally: only 36.4 percent of them had legal residence abroad. Borjas and Bratsberg (1996) argued that the failure of a migrant to obtain legal residence while abroad might determine his decision to return permanently back. Nevertheless, if a migrant does intend to return to his home country but does not intend to migrate again in the future, he is certainly more likely to overstay a work or tourist visa in order to fulfil, for example, his savings target.

With paid employment being the main reason for temporary migration, return and circular migrants were significantly more likely to work while abroad compared to permanent migrants. Nevertheless, they were also considerably more likely to work illegally.

The reason for returning differs notably between the forms of temporary migration. While the majority of return migrants moved back because of failing their migration target (45.9 percent; i.e. have not found work, have not obtained legal residence or have been deported) or after having accumulated enough savings (21.8 percent), 25.3 percent of the circular migrants have returned from the first trip because of the expiry of a seasonal/temporary work permit (compared to only 10.6 percent in the case of return migrants).

\footnotetext{
${ }^{7}$ Using data from the ALSMS 2002, Carletto et al. (2006) show similar geographical patterns of permanent and temporary migration.
} 
Finally, there seems to be quite a strong state dependency in circular migration: in 2005, 54.3 percent of the individuals that migrated repeatedly in the past (i.e. circular migrants) intend to migrate again during the next 12 months. In contrast, only 19.2 percent of the return migrants expressed their intention to re-migrate.

\section{Econometric Specification}

The migration decision processes described in Section 2 lead to alternative econometric models. If assuming a single utility maximisation migration decision over the life-time (i.e. Decision Tree 1 in Section2), the form of migration may be determined by a pairwise comparison of the indirect utilities of the given alternatives:

- no migration:

$$
U_{N}>U_{P}, U_{N}>U_{R}, U_{N}>U_{C},
$$

- permanent migration:

$$
U_{P}>U_{N}, U_{P}>U_{R}, U_{P}>U_{C},
$$

- return migration:

$$
U_{R}>U_{N}, U_{R}>U_{P}, U_{R}>U_{C},
$$

- circular migration:

$$
U_{C}>U_{N}, U_{C}>U_{P}, U_{C}>U_{R},
$$

where $N, P, R$, and $C$ stand for no migration, permanent migration, return migration, and circular migration respectively. The unordered choice settings can be motivated by a random utility model (Greene, 2002). For the $i$ th individual faced with $k=\{N, P, R, C\}$ choices, the utility of choice $j$ is given by:

$$
U_{i j}=\beta_{j} X_{i}+\varepsilon_{i j}
$$

where $U_{i j}$ is the indirect utility of choice $j$ for individual $i, x_{i}$ a vector of characteristics which affect the choice of the migration form, and $\beta_{j}$ a vector of choice-specific parameters.

Assumptions about the disturbances $\left(\varepsilon_{i j}\right)$ determine the nature of the model and the properties of its estimator. We assume that $\varepsilon_{i j}$ are independent and identically distributed with type I extreme value distribution, which leads to the multinomial logit model (Greene 2002; McFadden, 1974). The probability of choosing alternative $j$ is specified as:

$$
\operatorname{Pr}\left(y_{i}=j\right)=\frac{e^{\beta_{j} x_{i}}}{\sum_{k=N, P, R, C} e^{\beta_{k} x_{i}}}
$$

Not all $\beta_{j}$ in eq. (3) are identified and we normalise by setting $\beta_{N}=0$.

The dynamics among the possible choices in the estimation results of the multinomial logit model are illustrated by computing odds ratios. The factor change in the odds of 
outcome $m$ versus outcome $n$ for a marginal increase in $x_{k}$ and the other independent variables in the model held constant is given by:

$$
\frac{\Omega_{m \mid n}\left(\mathrm{x}, x_{k, m \mid n}+1\right)}{\Omega_{m \mid n}\left(\mathrm{x}, x_{k, m \mid n}\right)}=e^{\beta_{k, m \mid n}} .
$$

The limit of analysing the determinants of the migration form in the framework of a multinomial logit model is that one can control only for variables observed for all alternatives. One problem arising from that is the difficulty in some cases to infer the direction of causality. Many of the individuals’ socio-economic characteristics observed for all population groups (e.g. age, marital status, household size, or household income) are collected at the time of survey (i.e. in 2005). However, for migrants these might have been different at the time of their first migration episode, their return, or the subsequent migration trips. Therefore, some of the observed socio-economic characteristics may in fact be determined by the migration experience and the form of migration chosen. Moreover, the multinomial logit model does not allow to control for the effect of a previous migration experience (e.g. found work while abroad for the first time, legal residence while abroad, or reason for returning) on the decision to re-migrate, since non-migrants have no such experience. However, if we assume that the individual revises his initial migration decision after each migration step (Decision Tree 2 in Section 2), the migration experience would influence future migration movements. Nevertheless, running separate estimations only for migrants will give biased and inconsistent results, as migrants might be a non-randomly selected group.

In this respect, a more efficient model proves to be a probit with two sequential selfselection equations: the first equation controls for selection into migration while the second including only migrants - for the selection into return. This model can be estimated stepwise (i.e. the inverse Mill's ratio - IMR - of the first selection probit is introduced as a covariate in the second selection equation and the IMR from the second selection equation is then used as a covariate in the outcome probit) or by maximum likelihood. Relative to the maximum likelihood approach, the stepwise method is often perceived to give inconsistent results (Lahiri and Song, 2000). In particular, this is the case when there is strong multicolliniarity between covariates in the outcome equation and the selection controls (i.e. covariates of the selection equations). If there are no overlapping covariates in the outcome and selection equations, then multicolliniarity can be assumed insignificant (see Stolzenberg and Relles, 1997 and Nawata and Nagase, 1996). 
The equations for the probit model with two sequential selections have the following form for each observation:

- Migrant: $M^{*}=W^{\prime} \beta+m$, where $M=I\left(M^{*}>0\right)$

- Temporary migrant ${ }^{8}: T^{*}=Y^{\prime} \delta+t$, where $T=I\left(T^{*}>0\right)$ if $M=1$ and missing otherwise

- Circular migrant: $C^{*}=Z^{\prime} \theta+c$, where $C=I\left(C^{*}>0\right)$ if $T=1$ (and $M=1$ ) and missing otherwise.

The variables denoted by asterisks are the latent outcomes, and those without are binary indicators summarising the observed outcomes. $I($.$) is the indicator function equal to one if its$ argument is true, and zero otherwise. We assume the error terms $(m, t, c) \sim N_{3}(0, V)$, where $V$ is a symmetric matrix with typical element $\rho_{k l}=\rho_{l k}$ for $k, l \in\{m, t, c\}$ and $k \neq l$, and $\rho_{k k}=1$ for all $k$. The errors in each equation are assumed to be orthogonal to the predictors (elements of the vectors $W, Y$, and $Z$ respectively).

We define a set of signs variables $\kappa_{\tau}=2 \tau-1$ for $\tau \in\{M, T, C\}$. The likelihood contribution for a return migrant, i.e. with $M=1$ and $T=1$ is:

$$
L_{3}=\Phi_{3}\left(\kappa_{M} W^{\prime} \beta, \kappa_{T} Y^{\prime} \delta, \kappa_{C} Z^{\prime} \theta, \kappa_{M} \kappa_{T} \rho_{m t}, \kappa_{M} \kappa_{C} \rho_{m c}, \kappa_{T} \kappa_{C} \rho_{t c}\right)
$$

the likelihood contribution for a permanent migrant (i.e. $M=1$ and $T=0$ ) is:

$$
L_{2}=\Phi_{2}\left(\kappa_{M} W^{\prime} \beta, \kappa_{T} Y^{\prime} \delta, \kappa_{M} \kappa_{T} \rho_{m t}\right) \text {, }
$$

while the likelihood contribution for a non-migrant (i.e. $M=0$ ) is:

$$
L_{1}=\Phi_{1}\left(\kappa_{M} W^{\prime} \beta\right)
$$

It follows that the log-likelihood contribution to be calculated by the evaluator function for each observation is:

$$
\ln L=(1-M) \ln L_{1}+M(1-T) \ln L_{2}+M R \ln L_{3}
$$

\footnotetext{
${ }^{8}$ Temporary migration includes circular migration and return migration (i.e. permanent return after the first trip).
} 
In order to avoid multicolliniarty due to overlapping covariates in the outcome and selection equations, the model is estimated using maximum simulated likelihood (MSL) in Stata. We evaluate multivariate standard normal probabilities with 200 random draws using the mvnp() function by Cappellari and Jenkins (2006), a function based on the GewekeHajivassiliou-Keane (GHK) smooth recursive conditioning simulator. For the maximization, we used Stata's modified Newton-Raphson algorithm (see Gould et al., 2003). ${ }^{9}$

\section{Empirical Results}

The estimation results of the multinomial logit model of the choice of migration form are given in Table 2. Standard errors were adjusted for cluster sampling in the Albanian counties. ${ }^{10}$ The Small-Hsiao test for independence of irrelevant alternatives (IIA) holds for all subsets. Furthermore, the likelihood ratio tests for combining alternatives show that no pair of alternatives should be collapsed. ${ }^{11}$

The factor changes in odds among the subsets of equation 3 are presented in Table 3. As expected from the descriptive statistics, being a female decreases significantly the likelihood of being a migrant, in particular a circular migrant (see also Figure 1). Given the more traditional gender roles in the Albanian context, women are often in charge of taking care of children and household, while the men are the bread-earners (King et al., 2006). Therefore, it is not surprising that Albanian women often follow their husband in case he settles abroad, but are significantly less likely to engage in temporary migration for employment purposes. The gender difference between return and circular migration can be further explained through the gender difference in terms of the type of jobs they engage in, with men taking jobs with a more seasonal character, e.g. in construction, farming and tourism (ETF, 2007).

Age has a significant impact on the choice of migration form as well. As predicted by various migration models and confirmed by empirical findings, age decreases the odds of all forms of migration vs. non-migration. In particular, permanent migration seems to be a decision taken at a younger age (a marginal increase in age decreases the odds of permanent migration vs. non migration by a factor of 0.90 ; see Figure 2) as social and financial relocation costs are lower and the larger time span until the end of the active lifetime allows for higher gains from migration (Radu and Epstein, 2007). The second most affected by age is

\footnotetext{
${ }^{9}$ We would like thank Lorenzo Cappellari and Stephen Jenkins for advice on the Stata programming.

${ }^{10}$ The 12 counties are: Berat, Dibër, Durrës, Elbasan, Fier, Gjirokastër, Korçë, Kukës, Lezhë, Shkodër, Tirana and Vlorë.

${ }^{11}$ Test results are available from the authors upon request.
} 
circular migration: 9 percent lower odds compared to non migration and 3 percent lower odds compared to return migration. Circular migrants, being relatively less educated, are likely to start the migration process earlier in their life-time.

Even after controlling for other characteristics, tertiary education significantly and strongly decreases the likelihood of migration under any form, by factors of 0.50 to 0.64 . This could be evidence of relative higher returns to education in Albania and, therefore, "brain drain” should be less of a concern (see Borjas and Bratsberg, 1996). The relative return to education hypothesis is further confirmed by the fact that the better educated migrants return (i.e. being the marginal migrants, they would be the first to benefit in the home labour market from human capital accumulated abroad) and that lower educated individuals are motivated to migrate circularly and take advantage of the relatively higher earnings abroad for their (lower) education level.

From the three languages considered, speaking at least some Greek in 1990 has the strongest effect on migration. The common border of about $282 \mathrm{~km}$ and a shared culture and history (until 1990 a large Greek minority lived in the Southern part of Albania) made Greece the most important destination. Since the cost of crossing the Greek border (in particular illegally) is quite low, it is not surprising that speaking Greek mostly increases the odds of being a circular (8.24) or a return migrant (7.65) Nevertheless, probably due to the large exodus of ethnic Greeks at the beginning of the 1990s who were rapidly nationalised in Greece (see Barjaba, 2004), speaking Greek in 1990 also significantly increases the odds of permanent migration (5.63).

Family ties have conflicting effects on migration. On the one hand, being married increases strongly the odds of all migration forms, giving probably evidence to the fact that a married couple can reduce income risk if one spouse works abroad. On the other hand, the household size lowers the likelihood of being a migrant; the social ties within the family perhaps increasing the emotional cost of migration. Nevertheless, both being married and the household size significantly affect the form of migration, decreasing the amount of time per trip spent away from home (i.e. raising the odds of return vs. permanent migration but also of circular vs. return migration).

Number of migrants in the community has a positive impact on the decision to migrate, the strongest being on permanent and circular migration. This could be evidence that the culture of migration in the community has an important effect on the decision to migrate. Moreover, taking into account the relatively high migration failure rate among return migrants 
(46 percent), the existence of a strong community migrant network might prove essential for the success of the migration project.

Finally, the economic conditions and labour market opportunities in the region of origin seem to be an important determinant of the form of migration too. Individuals from rural areas are more prone to choose circular migration. Majority of them are most probably farmers, who add to small incomes from subsistence farming through seasonal work in Greece. Migrants from urban areas and districts with higher average wages are more likely to return permanently to Albania as they have higher chances of finding jobs or to start up a business with savings accumulated abroad.

The alternative model, through which the determinants of circular vs. return migration are assessed by MSL probit with double selection, is run under two specifications of the dependent variable. The first (Table 4) considers repeat migration movements in the past vs. having migrated only once. However, some of the returnees who have migrated only once (i.e. return migrants) may migrate again in the future and could be, in fact, circular migrants, even if we do not observe that. Assuming that individuals in this subgroup of return migrants have characteristics similar to circular migrants, our results could be biased. Therefore, in order to test the robustness of our results, in a second specification (Table 5), we consider the return migrants who intend to re-migrate in the next 12 months as circular migrants as well, while in the third specification (Table 6) they are excluded from the analysed sample.

Based on the results from the multinomial logit model (see Table 3), for both settings, the variables chosen to describe the selection into migration are: gender, education level, speaking Italian in 1990, speaking Greek in 1990, number of friends and the number of migrants in the community. Most selection instruments are significant and have the expected signs: gender and tertiary education negatively affect the probability of being a migrant, while secondary education, speaking the language of a neighbouring destination country and the number of migrants in the community (i.e. culture of migration or the migrant network) affect positively the probability of initial migration.

For the selection into temporary migration we used covariates observed only for migrants. Compared to settling permanently abroad, temporary migration is positively determined by the age at time of migration, illegal employment and migration to Greece, while the length of the trip, having obtained legal residence and having migrated with the children affect it negatively. A formal test for whether sample selection is ignorable is based on the null hypothesis that the cross-equation correlations are jointly different from zero. The test 
results show that for all settings the estimation results would have been biased and inconsistent, had we not corrected for selection. ${ }^{12}$

As robust outcomes (and similar to the results of the multinomial logit estimation), we find that circular migration is negatively affected by gender, age, secondary education and urban origin. Additionally, the return reason has strong and robust effect on the likelihood of having migrated repeatedly vs. having resettled permanently in Albania after the first migration trip. Failing the migration target is a negative experience that not only determines return migration (Borjas and Bratsberg, 1996) but seems to act as a deterrent for future migration movements as well. Similarly, everything else being equal, having accumulated enough savings during the first migration trip has a strong negative effect on the probability of being a circular migrant. Target savers may have intended from the very beginning to return permanently back after the first trip and start a business with the capital accumulated abroad, as argued by Mesnard (2004). Nevertheless, family reasons seem to be equally important in deterring further migration movements.

As for circular migration, it seems to be a choice made before leaving the country for the first time. Having returned from the first trip because of the expiry of a temporary/seasonal work permit significantly increases the likelihood of a repeat migration episode.

\section{Conclusions}

Theoretical and empirical evidence on the determinants of circular migration is still very limited and this paper is an attempt to fill the literature gap. We think the results obtained in this paper could be used as an aid in understanding the migration patterns and processes in order to design policies to more effectively manage migration for the benefit of both sending and receiving countries. Although the analysis is conducted using the Albanian dataset, the results could be generalised to other developing migrant sending countries as well, especially East European countries like Moldova, Bosnia and Herzegovina or Kosovo.

The main objective of the paper was to study the correlates and determinants of different forms of migration with a particular emphasis on circular migration. We chose Albania for our empirical analysis because it is a country of mass emigration and about one third of its aggregate migration movements are temporary. Furthermore, as in other East European countries, Albanian temporary migration hides different realities: about 50 percent

\footnotetext{
${ }^{12}$ Test results are available from the authors upon request.
} 
of the temporary migrants are returnees (i.e. have migrated abroad only once), while the other half are circular/repeat migrants.

Our empirical results show that the form of migration is determined by gender, age, the labour market prospects for specific skills, family ties, urban/rural origin, and past migration experience. For example, women and tertiary educated are more likely to stay put in Albania. The amount of time spent abroad, legal residence, and accompanying family are positively related to permanent migration, while age, secondary education, failed migration or fulfilment of a savings target determine permanent return after the first trip. Being a male, having a lower education level, originating from a rural area and having a positive temporary migration experience in the past are factors affecting circular migration.

Given that majority of the circular migrants are primary educated, their main contribution to development in Albania is probably through increasing the aggregate demand via remittances and repatriated savings. Nevertheless, development gains from transfers of skills and technology could probably be achieved through return migration. As shown by Piracha and Vadean (2009), many successful returnees start up own businesses and become entrepreneurs after settling back to Albania.

Our empirical results also confirm the hypothesis and empirical findings of Borjas and Bratsberg (1996) that, given the relative returns to skills in the home country, return migration accentuates the type of selection - in our case negative selection - that generated the initial migration flow. Additionally, our results provide evidence that re-migration of return migrants (i.e. circularity) further intensifies the initial selection; circular migrants being significantly less educated compared to migrants who return permanently to Albania after the first trip. 


\section{References}

Azzarri, C. and C. Carletto (2009), "Modelling Migration Dynamics in Albania A Hazard Function Approach”, Policy Research Working Paper 4945, Washington DC: The World Bank.

Barjaba, K. (2004), “Albania: Looking beyond borders”, mimeo, Washington DC: Migration Policy Institute.

Borjas, G. and B. Bratsberg (1996), "Who leaves? The out-migration of the foreign-born”, Review of Economics Statistics 78(1): 165-76.

Cappellari, L. and S.P. Jenkins (2006), “Calculation of multivariate normal probabilities by simulation, with applications to maximum simulated likelihood estimation”, Stata Journal 6(2): 156-89.

Carletto, C., B. Davis, M. Stampini and A. Zezza (2006), “A Country on the Move: International Migration in Post-Communist Albania”, International Migration Review 40(4): 767-85.

Constant, A. and K.F. Zimmermann (2007), “Circular Migration: Counts of Exits and Years Away from the Host Country”, IZA Discussion Paper No. 2999, Bonn: Institute for Study of Labor.

Dayton-Johnson, J., L.T. Katseli, G. Maniatis, R. Münz and D. Papademetriou (2007), “Gaining from Migration: Towards a New Mobility System”, Paris: OECD Development Centre.

Djajic, S. and R. Milbourne (1988), “A general equilibrium model of guest-worker migration: The source-country perspective”, Journal of International Economics 25(3-4): 335-51.

Dustmann, C. (2003), "Return migration, wage differentials and the optimal migration duration”, European Economic Review 47(2): 353-69.

Dustmann, C. (1997), “Return migration, uncertainty and precautionary savings”, Journal of Development Economics 52(2): 295-316.

Dustmann, C. (1995), "Savings behavior of migrant workers: A life-cycle analysis", Zeitschrift für Wirtschafts- und Sozialwissenschaften 115(4), 511-33.

ETF (2007), "The contribution of human resources development to migration policy in Albania”, Torino: European Training Foundation.

Gould, W., J. Pitblado and W. Sribney (2003), Maximum Likelihood Estimation with Stata, Second Edition, Stata Corp: Stata Press.

Greene, W.H. (2002), Econometric Analysis, 5th edition, New Jersey: Prentice-Hall. 
Hill, J.K. (1987), "Immigrant decisions concerning duration of stay and migratory frequency”, Journal of Development Economics 25(1): 221-34.

King, R., M. Dalipaj and N. Mai (2006), “Gendering Migration and Remittances: Evidence from London and Northern Albania”, Population Space and Place 12(6): 409-34.

Lahiri, K. and J.G. Song (2000), “The effect of smoking on health using a sequential selfselection model”, Health Economics 9(6): 491-511.

Massey, D.S. and K.E. Espinosa (1997), "What's Driving Mexico-U.S. Migration? A Theoretical, Empirical, and Policy Analysis”, The American Journal of Sociology 102(4): 939-99.

McFadden, D. (1974), “The Measurement of Urban Travel Demand”, Journal of Public Economics 3(4): 303-28.

Mesnard, A. (2004), “Temporary migration and capital market imperfections”, Oxford Economic Papers 56(2): 242-62.

Nawata, K. and N. Nagase (1996), "Estimation of sample selection bias models", Econometris Reviews 15(4): 387-400.

Radu, D.C. and G. Epstein (2007), "Returns to return migration and determinants of subsequent moves”, EALE Conference Paper, EALE Annual Conference, 20-22 September 2007, Oslo.

Piracha, M. and F. Vadean (2009), "Return Migration and Occupational Choice”, Department of Economics Discussion Paper 09/05, Canterbury: University of Kent.

Stark, O. (1991), The Migration of Labour, Basil Blackwell, Oxford.

Stark O. and J.E. Taylor (1991), “Migration incentives, migration types: The role of relative deprivation”, The Economic Journal 101(408): 1163-78.

Stolzenberg, R.M. and D.A. Relles (1997), "Tools for intuition about sample selection bias ant its correction”, American Sociological Review 62 (3): 494-507.

Vullnetari, J. (2007), “Albanian Migration and Development: State of the Art Review”, IMISCOE Working Paper No. 18, Amsterdam: Institute for Migration and Ethnic Studies (IMES). 
Table 1: Descriptive statistics by form of migration

\begin{tabular}{|c|c|c|c|c|c|c|c|}
\hline & $\begin{array}{c}\text { Non } \\
\text { migrants } \\
\end{array}$ & & $\begin{array}{c}\text { Permanent } \\
\text { migrants }\end{array}$ & & $\begin{array}{c}\text { Return } \\
\text { migrants }\end{array}$ & & $\begin{array}{l}\text { Circular } \\
\text { migrants } \\
\end{array}$ \\
\hline & Mean value & difference & Mean value & difference & Mean value & difference & Mean value \\
\hline \multicolumn{8}{|l|}{ Individual Characteristics } \\
\hline Gender (female $=1$ ) & 0.522 & $0.171^{\star \star \star}$ & 0.350 & $0.268^{\star * *}$ & 0.082 & $0.068^{* \star *}$ & 0.014 \\
\hline Age & 39.422 & $6.623^{\star \star \star}$ & 32.799 & $-4.492^{\star * \star}$ & 37.291 & $1.744^{\star \star \star}$ & 35.547 \\
\hline Education level: primary & 0.485 & $0.040 * * \star$ & 0.445 & 0.027 & 0.418 & $-0.139 * * \star$ & 0.557 \\
\hline Education level: secondary & 0.389 & $-0.070^{* \star *}$ & 0.459 & -0.035 & 0.494 & $0.095^{\star * \star}$ & 0.400 \\
\hline Education level: tertiary & 0.126 & $0.030^{\star \star \star}$ & 0.096 & 0.008 & 0.088 & $0.045^{\star \star \star}$ & 0.043 \\
\hline Speaks English (1990) & 0.050 & $-0.042^{\star \star \star}$ & 0.092 & $0.034^{\star \star}$ & 0.058 & $0.038^{\star \star \star}$ & 0.020 \\
\hline Speaks Italian (1990) & 0.057 & $-0.066^{\star \star \star}$ & 0.123 & $0.037^{\star *}$ & 0.086 & $0.052^{\star \star *}$ & 0.034 \\
\hline Speaks Greek (1990) & 0.009 & $-0.051^{\text {*** }}$ & 0.059 & -0.011 & 0.071 & 0.006 & 0.065 \\
\hline Married & 0.799 & $0.165^{\star \star \star}$ & 0.634 & $-0.165^{\star \star \star}$ & 0.799 & -0.008 & 0.806 \\
\hline \multicolumn{8}{|l|}{ Household Characteristics } \\
\hline HH subjective economic status in 1990 & 3.571 & $0.095^{\star}$ & 3.476 & -0.171 & 3.647 & $0.438^{\star \star *}$ & 3.210 \\
\hline HH subjective economic status in 2005 & 3.818 & $-0.200 * \star \star$ & 4.018 & -0.038 & 4.056 & $0.294^{\star \star \star}$ & 3.762 \\
\hline Log of $\mathrm{HH}$ income & 12.363 & $0.408^{\star \star \star}$ & 11.956 & $-0.497^{\star \star \star}$ & 12.452 & $0.421^{\star \star \star}$ & 12.031 \\
\hline $\mathrm{HH}$ size & 4.859 & $1.681^{\star \star \star}$ & 3.178 & $-1.618^{\star \star \star}$ & 4.797 & $-0.354^{\star \star \star}$ & 5.151 \\
\hline Number of friends & 1.953 & $0.224^{\star \star \star}$ & 1.729 & $-0.426^{\star \star \star}$ & 2.155 & $0.322^{\star \star \star}$ & 1.833 \\
\hline \multicolumn{8}{|l|}{ Community and Regional Characteristics } \\
\hline Urban area & 0.529 & $-0.037^{\star *}$ & 0.566 & -0.011 & 0.576 & $0.204^{\star * *}$ & 0.373 \\
\hline Region: Coastal & 0.250 & $-0.165^{\star \star \star}$ & 0.415 & $0.098^{\star \star \star}$ & 0.317 & 0.045 & 0.272 \\
\hline Region: Central & 0.286 & 0.011 & 0.276 & -0.010 & 0.285 & $-0.048^{*}$ & 0.333 \\
\hline Region: Mountain & 0.288 & $0.138^{\star \star *}$ & 0.150 & $-0.050 * \star \star$ & 0.200 & $-0.121^{\star \star \star}$ & 0.321 \\
\hline Region: Tirana & 0.176 & 0.016 & 0.160 & $-0.038^{\star \star}$ & 0.198 & $0.124^{\star \star \star}$ & 0.073 \\
\hline Average wage at district level (LEK) & $30,886.23$ & $297.60^{\star *}$ & $30,588.63$ & $-607.68^{\star \star \star}$ & $31,196.31$ & $1,743.90^{* \star *}$ & $29,452.41$ \\
\hline Number of migrants in community (PSU) & 6.920 & $-3.715^{\star \star *}$ & 10.635 & $1.822^{* * *}$ & 8.813 & $-0.545^{\star \star}$ & 9.358 \\
\hline
\end{tabular}


Table 1: Descriptive statistics by form of migration (continued)

\begin{tabular}{|c|c|c|c|c|c|c|c|}
\hline & $\begin{array}{c}\text { Non } \\
\text { migrants }\end{array}$ & & $\begin{array}{c}\text { Permanent } \\
\text { migrants }\end{array}$ & & $\begin{array}{l}\text { Return } \\
\text { migrants }\end{array}$ & & $\begin{array}{l}\text { Circular } \\
\text { migrants }\end{array}$ \\
\hline & Mean value & difference & Mean value & difference & Mean value & difference & Mean value \\
\hline \multicolumn{8}{|l|}{ Migration history (first migration trip) } \\
\hline Age at first migration trip & & & 25.126 & $-4.270^{\star \star \star}$ & 29.396 & $2.919^{\star \star \star}$ & 26.477 \\
\hline Length of first migration trip & & & 92.081 & $70.012^{* * *}$ & 22.069 & $12.610^{\star \star *}$ & 9.459 \\
\hline Legal residence during first migration trip & & & 0.899 & $0.535^{\star \star \star}$ & 0.364 & $0.125^{\star \star \star}$ & 0.238 \\
\hline Legal residence during last migration trip & & & 0.899 & $0.535^{\star \star \star}$ & 0.364 & $-0.181^{\star \star \star}$ & 0.545 \\
\hline Work during first migration trip: no & & & 0.160 & $0.071^{\star \star \star}$ & 0.090 & $0.029^{*}$ & 0.061 \\
\hline Work during first migration trip: legally & & & 0.748 & $0.399 * * \star$ & 0.349 & $0.050^{*}$ & 0.299 \\
\hline Work during first migration trip: illegally & & & 0.092 & $-0.469^{\star * *}$ & 0.562 & $-0.078^{\star \star \star}$ & 0.640 \\
\hline Married: no & & & 0.277 & $-0.091 * * *$ & 0.368 & $-0.120^{\star \star *}$ & 0.487 \\
\hline Married: migrated with spouse & & & 0.640 & $0.481^{\star \star *}$ & 0.159 & 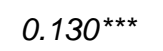 & 0.029 \\
\hline Married: spouse in Albania & & & 0.083 & $-0.391 * \star \star$ & 0.474 & -0.010 & 0.484 \\
\hline Children: no & & & 0.352 & $-0.107^{* \star *}$ & 0.459 & $-0.075^{\star \star}$ & 0.534 \\
\hline Children: migrated with children & & & 0.562 & $0.459^{\star \star \star}$ & 0.103 & $0.081^{\star \star *}$ & 0.022 \\
\hline Children: children in Albania & & & 0.086 & $-0.352^{\star * \star}$ & 0.438 & -0.006 & 0.444 \\
\hline Migrated to Greece & & & 0.411 & $-0.337^{\star * *}$ & 0.748 & $-0.132 * * \star$ & 0.880 \\
\hline Migrated to Italy & & & 0.379 & $0.213^{\star \star \star}$ & 0.166 & $0.100 * \star \star$ & 0.066 \\
\hline Migrated to other country & & & 0.210 & $0.124^{\star \star \star}$ & 0.086 & $0.032^{* *}$ & 0.054 \\
\hline Age at first return & & & & & 31.235 & 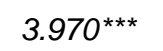 & 27.265 \\
\hline Return reason: family/non economic & & & & & 0.216 & $0.095^{\star \star \star}$ & 0.122 \\
\hline Return reason: unsuccessful & & & & & 0.459 & -0.046 & 0.505 \\
\hline Return reason: temporary/seasonal permit & & & & & 0.106 & $-0.146^{\star \star \star}$ & 0.253 \\
\hline Return reason: accumulated enough savings & & & & & 0.218 & $0.098^{\star \star *}$ & 0.120 \\
\hline Re-migration intention: yes & & & & & 0.192 & $-0.351^{\star \star \star}$ & 0.543 \\
\hline Re-migration intention: no & & & & & 0.646 & $0.362^{\star \star \star}$ & 0.283 \\
\hline Re-migration intention: don't know & & & & & 0.162 & -0.012 & 0.174 \\
\hline Observations & 4,756 & & 1,430 & & 536 & & 558 \\
\hline
\end{tabular}

Notes: The sample included is the potential labour force (i.e. not enrolled in education, not a housewife/-husband, not retired, not handicapped, and not in military service) aged 20 to 60 . $\mathrm{HH}$ subjective economic status: $1=$ poor to $10=$ rich. The differences are computed between the mean values in the adjoining columns. 
Table 2: Multinomial Logit estimation of choice among migration forms

\begin{tabular}{|c|c|c|c|}
\hline & $\begin{array}{l}\text { Permanent migrant } \\
\text { vs. Non migrant } \\
\end{array}$ & $\begin{array}{c}\text { Return migrant vs. } \\
\text { Non migrant }\end{array}$ & $\begin{array}{c}\text { Circular migrant vs. } \\
\text { Non migrant }\end{array}$ \\
\hline \multicolumn{4}{|l|}{ Individual Characteristics } \\
\hline \multirow[t]{2}{*}{ Gender (female = 1) } & -1.16001 & -2.96162 & -4.98761 \\
\hline & {$[0.13634]^{\star \star \star}$} & {$[0.19971]^{\star \star \star}$} & {$[0.42093]^{\star \star \star}$} \\
\hline \multirow[t]{2}{*}{ Age } & -0.10814 & -0.0647 & -0.09308 \\
\hline & {$[0.00729]^{\star \star \star}$} & {$[0.00533]^{\star \star \star}$} & {$[0.00714]^{\star \star \star}$} \\
\hline \multirow[t]{2}{*}{ Education level: secondary } & 0.15244 & 0.20663 & 0.01752 \\
\hline & {$[0.10275]$} & {$[0.08121]^{\star \star}$} & {$[0.08146]$} \\
\hline \multirow[t]{2}{*}{ Education level: tertiary } & -0.68525 & -0.44185 & -0.57404 \\
\hline & {$[0.24132]^{\star \star \star}$} & [0.29003] & {$[0.28535]^{\star \star}$} \\
\hline \multirow[t]{2}{*}{ Speaks English (in 1990) } & 0.40394 & 0.02481 & -0.19694 \\
\hline & {$[0.31354]$} & {$[0.23567]$} & [0.34043] \\
\hline \multirow[t]{2}{*}{ Speaks Italian (in 1990) } & 0.50185 & 0.47912 & 0.16864 \\
\hline & [0.32705] & {$[0.28007]^{\star}$} & [0.45261] \\
\hline \multirow[t]{2}{*}{ Speaks Greek (in 1990) } & 1.72834 & 2.03414 & 2.10866 \\
\hline & {$[0.34696]^{\star \star \star}$} & {$[0.18069]^{\star \star \star}$} & {$[0.51933]^{\star \star \star}$} \\
\hline \multirow[t]{2}{*}{ Married } & 0.53196 & 1.07557 & 1.60809 \\
\hline & {$[0.19997]^{\star \star \star}$} & {$[0.15940]^{\star \star \star}$} & {$[0.20682]^{\star \star \star}$} \\
\hline \multicolumn{4}{|l|}{ Household Characteristics } \\
\hline \multirow[t]{2}{*}{ HH subjective economic status in 1990} & -0.04367 & 0.01181 & -0.02296 \\
\hline & {$[0.03793]$} & [0.02589] & [0.04327] \\
\hline \multirow[t]{2}{*}{$\mathrm{HH}$ size } & -0.77753 & -0.06617 & -0.02224 \\
\hline & {$[0.02711]^{\star \star \star}$} & {$[0.02489]^{\star \star *}$} & [0.02562] \\
\hline \multirow[t]{2}{*}{ Number of friends } & -0.02129 & 0.07319 & -0.03991 \\
\hline & {$[0.02819]$} & {$[0.02030]^{\star \star \star}$} & [0.05393] \\
\hline \multicolumn{4}{|l|}{ Regional Characteristics } \\
\hline \multirow[t]{2}{*}{ Number of migrants in the community } & 0.19938 & 0.14632 & 0.15929 \\
\hline & {$[0.00951]^{\star \star \star}$} & {$[0.01840]^{\star \star \star}$} & {$[0.02095]^{\star \star \star}$} \\
\hline \multirow[t]{2}{*}{ Urban area } & 0.16214 & 0.27318 & -0.12512 \\
\hline & [0.10524] & {$[0.09816]^{\star \star \star}$} & [0.11110] \\
\hline \multirow[t]{2}{*}{ Log of average wage (district level) } & -0.40163 & 0.64509 & -2.59168 \\
\hline & {$[0.23697]^{\star}$} & {$[0.34892]^{*}$} & {$[1.49510]^{*}$} \\
\hline \multirow[t]{2}{*}{ Constant } & 8.34078 & -7.75753 & 26.64024 \\
\hline & {$[2.35848]^{\star \star \star}$} & {$[3.61103]^{\star \star}$} & {$[15.51550]^{*}$} \\
\hline Observations & & 7,280 & \\
\hline Pseudo R-sq & & 0.29 & \\
\hline
\end{tabular}

Robust standard errors in brackets; adjusted for 12 clusters (i.e. counties)

* significant at 10\%; ** significant at 5\%; *** significant at 1\%

Notes: HH subjective economic status1990: 1=poor to 10=rich. 
Table 3: Odds ratios for choice among migration forms

\begin{tabular}{|c|c|c|c|c|c|c|c|}
\hline & Gender & Age & $\begin{array}{c}\text { Education } \\
\text { level: } \\
\text { secondary }\end{array}$ & $\begin{array}{c}\text { Education } \\
\text { level: } \\
\text { tertiary } \\
\end{array}$ & $\begin{array}{c}\text { Speaks } \\
\text { English } \\
(1990)\end{array}$ & $\begin{array}{l}\text { Speaks } \\
\text { Italian } \\
(1990) \\
\end{array}$ & $\begin{array}{c}\text { Speaks } \\
\text { Greek } \\
(1990) \\
\end{array}$ \\
\hline P vs. $\mathrm{N}$ & $0.31^{* * *}$ & $0.90^{* * *}$ & 1.16 & $0.50 * \star \star$ & 1.50 & 1.65 & $5.63^{\star \star \star}$ \\
\hline R vs. N & $0.05^{\star \star *}$ & $0.94^{\star \star *}$ & $1.23^{\star *}$ & 0.64 & 1.03 & $1.61^{*}$ & $7.65^{\star \star *}$ \\
\hline R vs. P & $0.17^{\star \star *}$ & $1.04^{\star \star \star}$ & 1.06 & 1.28 & 0.68 & 0.98 & 1.36 \\
\hline C vs. N & $0.01^{\star * *}$ & $0.91^{\star \star *}$ & 1.02 & $0.56^{\star \star}$ & 0.82 & 1.18 & $8.24^{\star \star \star}$ \\
\hline C vs. P & $0.02^{* * *}$ & 1.02 & 0.87 & 1.12 & 0.55 & 0.72 & 1.46 \\
\hline C vs. R & $0.13^{\star * \star}$ & $0.97^{\star \star \star}$ & $0.83^{\star \star}$ & 0.88 & 0.80 & 0.73 & 1.08 \\
\hline
\end{tabular}

* significant at $10 \% ;{ }^{* \star}$ significant at $5 \%$; ${ }^{\star \star \star}$ significant at $1 \%$

Table 3: Odds ratios for choice among migration forms (continued)

\begin{tabular}{|c|c|c|c|c|c|c|c|}
\hline & Married & $\begin{array}{c}\text { Subjective } \\
\text { econ. } \\
\text { status } 1990 \\
\end{array}$ & $\mathrm{HH}$ size & $\begin{array}{l}\text { No. of } \\
\text { friends }\end{array}$ & $\begin{array}{l}\text { No. of } \\
\text { migrants in } \\
\text { community }\end{array}$ & Urban area & $\begin{array}{c}\text { Log of av. } \\
\text { wages } \\
\text { (district) }\end{array}$ \\
\hline$P$ vs. $N$ & $1.70^{\star \star \star}$ & 0.96 & $0.46^{\star \star \star}$ & 0.98 & $1.22^{\star \star \star}$ & 1.18 & $0.67^{*}$ \\
\hline R vs. N & $2.93^{\star * *}$ & 1.01 & $0.94^{\star \star \star}$ & $1.08^{\star \star *}$ & $1.16^{\star \star \star}$ & $1.31^{\star \star \star}$ & $1.91^{*}$ \\
\hline R vs. P & $1.72^{\star \star \star}$ & 1.06 & $2.04^{\star \star \star}$ & $1.10^{\star \star \star}$ & $0.95^{\star \star \star}$ & 1.12 & $2.85^{\star \star \star}$ \\
\hline $\mathrm{C}$ vs. $\mathrm{N}$ & $4.99 * \star \star$ & 0.98 & 0.98 & 0.96 & $1.17^{\star \star \star}$ & 0.88 & $0.07^{\star}$ \\
\hline C vs. P & $2.93^{\star * *}$ & 1.02 & $2.13^{\star \star \star}$ & 0.98 & $0.96 * \star$ & $0.75^{\star}$ & 0.11 \\
\hline C vs. R & $1.70^{\star}$ & 0.97 & 1.04 & $0.89 *$ & 1.01 & $0.67^{\star \star *}$ & $0.04^{*}$ \\
\hline
\end{tabular}

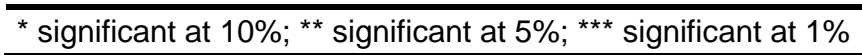

Notes: Odds ratios computed based on the estimation in Table 2. HH subjective economic status 1990: 1=poor to $10=$ rich. 
Table 4: MSL three-variate probit with two selections of the decision to migrate circularly

Migration equation

Gender (female $=1$ )

Education level: secondary

Education level: tertiary

Spoke Italian in 1990

Spoke Greek in 1990

Number of friends

Number of migrants in the community

Constant

Temporary migration equation
Age at first migration trip

Months remained away (first trip)

Obtained legal residence (first trip)

Worked abroad during first trip: legally

Worked abroad during first trip: illegally

Married: migrated with spouse

Married: spouse in Albania

Children: migrated with children

Children: children in Albania

Country of destination: Greece

Country of destination: Italy

\section{Constant}

Total number of observations

Number of migrants

Number of returnees

Number of circular migrants

Log of pseudo likelihood

\begin{tabular}{|c|c|c|}
\hline & Circular miaration equation & \\
\hline-0.91659 & Gender (female = 1) & -0.67789 \\
\hline$[0.10377]^{\star \star \star}$ & & {$[0.23921]^{\star \star \star}$} \\
\hline 0.12875 & Age after first migration trip & -0.03904 \\
\hline$[0.04893]^{\star \star *}$ & & {$[0.00599]^{\star \star \star}$} \\
\hline-0.2378 & Education level: secondary & -0.1206 \\
\hline$[0.09147]^{\star \star \star}$ & & {$[0.05034]^{\star *}$} \\
\hline 0.56879 & Education level: tertiary & 0.03331 \\
\hline$[0.04634]^{\star \star \star}$ & & {$[0.23080]$} \\
\hline 1.08148 & Married at time of the first migration & 0.13678 \\
\hline$[0.08178]^{\star \star \star}$ & & {$[0.12662]$} \\
\hline-0.01718 & Economic situation in 1990 & -0.01862 \\
\hline$[0.01828]$ & & {$[0.03457]$} \\
\hline 0.1016 & Log of $\mathrm{HH}$ income & -0.03633 \\
\hline$[0.00598]^{\star \star *}$ & & [0.03414] \\
\hline-0.96729 & $\mathrm{HH}$ size & -0.01876 \\
\hline$[0.15450]^{\star \star \star}$ & & {$[0.01590]$} \\
\hline & Urban location & $\begin{array}{c}-0.15967 \\
{[0.07510]^{\star *}}\end{array}$ \\
\hline 0.02425 & Log of average wage (district level) & -1.55591 \\
\hline$[0.00680]^{\star \star \star}$ & & {$[0.75343]^{\star \star}$} \\
\hline-0.02914 & Returned from Greece & 0.16508 \\
\hline$[0.00437]^{\star \star \star}$ & & [0.30151] \\
\hline-0.50115 & Returned from Italy & -0.27712 \\
\hline$[0.12608]^{\star \star \star}$ & & {$[0.34960]$} \\
\hline 0.10122 & Return reason: family/non economic & -0.57042 \\
\hline [0.16954] & & {$[0.21044]^{\star \star *}$} \\
\hline 0.38536 & Return reason: unsuccessful & -0.50653 \\
\hline$[0.11610]^{\star \star \star}$ & & {$[0.19649]^{\star \star \star}$} \\
\hline 0.03323 & Return reason: acc. enough savings & -0.56418 \\
\hline$[0.21631]$ & & {$[0.21610]^{\star \star \star}$} \\
\hline 0.31093 & Constant & 18.51599 \\
\hline$[0.26471]$ & & {$[7.77962]^{\star *}$} \\
\hline-0.89996 & & \\
\hline$[0.18851]^{\star \star \star}$ & & \\
\hline $\begin{array}{l}-0.14535 \\
{[0.23423]}\end{array}$ & Cross-equation correlations & \\
\hline 0.91165 & r21 r r r & -0.31173 \\
\hline$[0.20041]^{\star \star \star}$ & & {$[0.11404]^{\star \star \star}$} \\
\hline-0.00563 & r31 & -0.26464 \\
\hline [0.22281] & & [0.16325] \\
\hline 0.82576 & r32 & -0.31071 \\
\hline$[0.28582]^{\star \star \star}$ & & {$[0.09712]^{\star \star \star}$} \\
\hline 7,280 & & \\
\hline 2,524 & & \\
\hline 1,094 & & \\
\hline 558 & & \\
\hline-4976.33 & & \\
\hline
\end{tabular}

Robust standard errors in brackets; adjusted for 12 clusters (i.e. counties)

* significant at $10 \%$; ** significant at $5 \%$; *** significant at $1 \%$

Notes: The dependent variable of the migration equation has the value " 1 " if the individual is a migrant and " 0 " if the individual is a non-migrant; the dependent variable of the temporary migration equation has the value " 1 " if the individual is a temporary (i.e. circular or return) migrant and "0" if the individual is a permanent migrant; the dependent variable of the circular migration equation has the value " 1 " if the individual is a circular migrant and " 0 " if the individual is a return migrant. $\mathrm{HH}$ subjective economic status: $1=$ poor to $10=$ rich. The control group for working abroad during migration trip is "No work", for marital status is "Not married", for children is "No children", for the countries of destination is "Other"; and for the return reasons is "Seasonal/temporary migration". 
Table 5: MSL three-variate probit with two selections of the decision to migrate circularly (returnees who migrated only once but intend to re-migrate considered also as circular migrants) Migration equation

Gender (female $=1$ )

Circular migration equation

Education level: secondary

$-0.91661$

$[0.10369]^{\star \star \star}$

0.12774

$[0.04941]^{\star \star \star *}$

$-0.24013$

Education level: tertiary

$[0.09250]^{\star \star \star}$

0.57557

Spoke Italian in 1990

$[0.04419]^{\star \star *}$

1.08057

Spoke Greek in 1990

$[0.08295]^{\star \star \star}$

Number of friends

$-0.01467$

[0.01825]

Number of migrants in the community

0.10155

Constant

$[0.00609]^{\star \star *}$

$-0.97139$

$[0.15360]^{\star \star \star}$

\begin{tabular}{|c|c|c|c|}
\hline & {$[0.15360]^{n n}$} & & [0.0<695] \\
\hline Temporary migration equation & 0.02474 & Urban location & $\begin{array}{c}-0.18218 \\
{[0.10850]^{*}}\end{array}$ \\
\hline Age at first migration trip & $\begin{array}{c}{[0.00633]^{\star \star *}} \\
-0.02877\end{array}$ & Log of average wage (district level) & $\begin{array}{l}-0.80253 \\
{[0.65532]}\end{array}$ \\
\hline Months remained away (first trip) & $\begin{array}{c}{[0.00442]^{\star \star *}} \\
-0.50656\end{array}$ & Returned from Greece & $\begin{array}{c}0.08547 \\
{[0.31781]}\end{array}$ \\
\hline Obtained legal residence (first trip) & $\begin{array}{c}{[0.12677]^{\star \star \star}} \\
0.0874\end{array}$ & Returned from Italy & $\begin{array}{l}-0.33527 \\
{[0.40772]}\end{array}$ \\
\hline Worked abroad during first trip: legally & $\begin{array}{c}{[0.17506]} \\
0.39237\end{array}$ & Return reason: family/non economic & $\begin{array}{c}-0.53103 \\
{[0.19322]^{\star \star \star}}\end{array}$ \\
\hline Worked abroad during first trip: illegally & $\begin{array}{c}{[0.11895]^{\star \star \star *}} \\
0.04775\end{array}$ & Return reason: unsuccessful & $\begin{array}{c}-0.71773 \\
{[0.17778]^{\star \star *}}\end{array}$ \\
\hline Married: migrated with spouse & $\begin{array}{c}{[0.21097]} \\
0.31194\end{array}$ & Return reason: acc. enough savings & $\begin{array}{c}-0.88559 \\
{[0.17988]^{\star \star \star}}\end{array}$ \\
\hline Married: spouse in Albania & $\begin{array}{c}{[0.25262]} \\
-0.92569\end{array}$ & Constant & $\begin{array}{l}11.89913 \\
{[7.32821]}\end{array}$ \\
\hline Children: migrated with children & $\begin{array}{c}{[0.18846]^{\star \star \star}} \\
-0.15783\end{array}$ & & \\
\hline Children: children in Albania & $\begin{array}{c}{[0.21528]} \\
0.92127\end{array}$ & Cross-equation correlations & \\
\hline Country of destination: Greece & $\begin{array}{c}{[0.19885]^{\star \star * *}} \\
-0.00767\end{array}$ & & $\begin{array}{c}-0.33162 \\
{[0.11032]^{\star \star \star}}\end{array}$ \\
\hline Country of destination: Italy & $\begin{array}{c}{[0.22120]} \\
0.82235\end{array}$ & r31 & $\begin{array}{c}-0.01714 \\
{[0.13980]}\end{array}$ \\
\hline Constant & $\begin{array}{c}{[0.27735]^{\star \star \star}} \\
0.02474 \\
\end{array}$ & r32 & $\begin{array}{l}-0.15234 \\
{[0.12100]} \\
\end{array}$ \\
\hline Total number of observations & 7,280 & & \\
\hline Number of migrants & 2,524 & & \\
\hline Number of returnees & 1,094 & & \\
\hline Number of circular migrants & 661 & & \\
\hline Log of pseudo likelihood & -4962.65 & & \\
\hline
\end{tabular}

Robust standard errors in brackets; adjusted for 12 clusters (i.e. counties)

* significant at 10\%; ** significant at 5\%; *** significant at $1 \%$

Notes: The dependent variable of the migration equation has the value " 1 " if the individual is a migrant and " 0 " if the individual is a non-migrant; the dependent variable of the temporary migration equation has the value " 1 " if the individual is a temporary (i.e. circular or return) migrant and " 0 " if the individual is a permanent migrant; the dependent variable of the circular migration equation has the value " 1 " if the individual is a circular migrant and " 0 " if the individual is a return migrant. $\mathrm{HH}$ subjective economic status: $1=$ poor to $10=$ rich. The control group for working abroad during migration trip is "No work", for marital status is "Not married", for children is "No children", for the countries of destination is "Other"; and for the return reasons is "Seasonal/temporary migration". 
Table 6: MSL three-variate probit with two selections of the decision to migrate circularly (returnees who migrated only once but intend to re-migrate excluded from the sample)

Migration equation

Gender (female = 1)

Circular migration equation

Education level: secondary

$-0.89673$

$[0.10338]^{\star \star *}$

0.14253

Education level: tertiary

$[0.04488]^{\star \star \star}$

$-0.21135$

$[0.08915]^{\star *}$

0.57484

Spoke Italian in 1990

$[0.04145]^{\star \star *}$

1.09299

Spoke Greek in 1990

$[0.08347]^{\star * *}$

$-0.01732$

Number of friends

[0.01842]

Number of migrants in the community

0.1034

$[0.00568]^{\star \star *}$

$-1.02545$

Constant

Gender (female $=1$ )

$-0.72006$

Age after first migration trip

$[0.22389]^{\star \star \star}$

$-0.04485$

Education level: secondary

$-0.17537$

Education level: tertiary

$[0.05880]^{\star \star \star}$

$-0.0915$

[0.25497]

Married at time of the first migration $\quad 0.13354$

[0.13706]

Economic situation in 1990

$-0.01235$

[0.03979]

Log of $\mathrm{HH}$ income

$-0.11281$

$[0.05495]^{\star \star}$

0.00707

$[0.14101]^{\star \star \star}$

Temporary migration equation

Age at first migration trip

Months remained away (first trip)

Obtained legal residence (first trip)

$\mathrm{HH}$ size

[0.02184]

Urban location

$-0.14086$

$[0.08367]^{\star}$

$-1.36635$

$[0.79217]^{\star}$

0.08162

[0.33931]

$-0.40662$

[0.41455]

$-0.66769$

Worked abroad during first trip: legally

$-0.52249$

$[0.11983]^{\star \star *}$

0.12373

$[0.22519]^{\star \star \star}$

[0.15949]

Worked abroad during first trip: illegally

0.38191

$[0.13233]^{\star \star *}$

0.14536

[0.22792]

0.45403

Married: spouse in Albania

Children: migrated with children

$[0.22442]^{\star \star}$

$-0.80377$

Return reason: family/non economic

$-0.73812$

$[0.20130]^{\star \star \star *}$

Return reason: acc. enough savings

$-0.80716$

$[0.19721]^{\star \star \star}$

Constant

17.86279

$[8.64810]^{\star *}$

Children: children in Albania

$[0.21092]^{\star \star *}$

$-0.2087$

[0.19622]

0.91837

Country of destination: Greece

$[0.23340]^{\star \star \star *}$

$-0.0021$

[0.26049]

1.02466

Constant

$[0.35347]^{\star \star \star *}$

Cross-equation correlations

r21

$-0.36648$

$[0.11193]^{\star \star \star}$

r31

$-0.13081$

[0.16799]

$-0.33061$

7,177

Total number of observations

2,431

Number of migrants

Number of returnees

558

Number of circular migrants

Log of pseudo likelihood

$-4731.33$

$[0.11617]^{\star * *}$

Robust standard errors in brackets; adjusted for 12 clusters (i.e. counties)

* significant at $10 \%$; ** significant at $5 \%$; *** significant at $1 \%$

Notes: The dependent variable of the migration equation has the value " 1 " if the individual is a migrant and " 0 " if the individual is a non-migrant; the dependent variable of the temporary migration equation has the value " 1 " if the individual is a temporary (i.e. circular or return) migrant and " 0 " if the individual is a permanent migrant; the dependent variable of the circular migration equation has the value " 1 " if the individual is a circular migrant and " 0 " if the individual is a return migrant. $\mathrm{HH}$ subjective economic status: $1=$ poor to $10=$ rich. The control group for working abroad during migration trip is "No work", for marital status is "Not married", for children is "No children", for the countries of destination is "Other"; and for the return reasons is "Seasonal/temporary migration". 
Figure 1: Predicted probabilities of migration form by gender

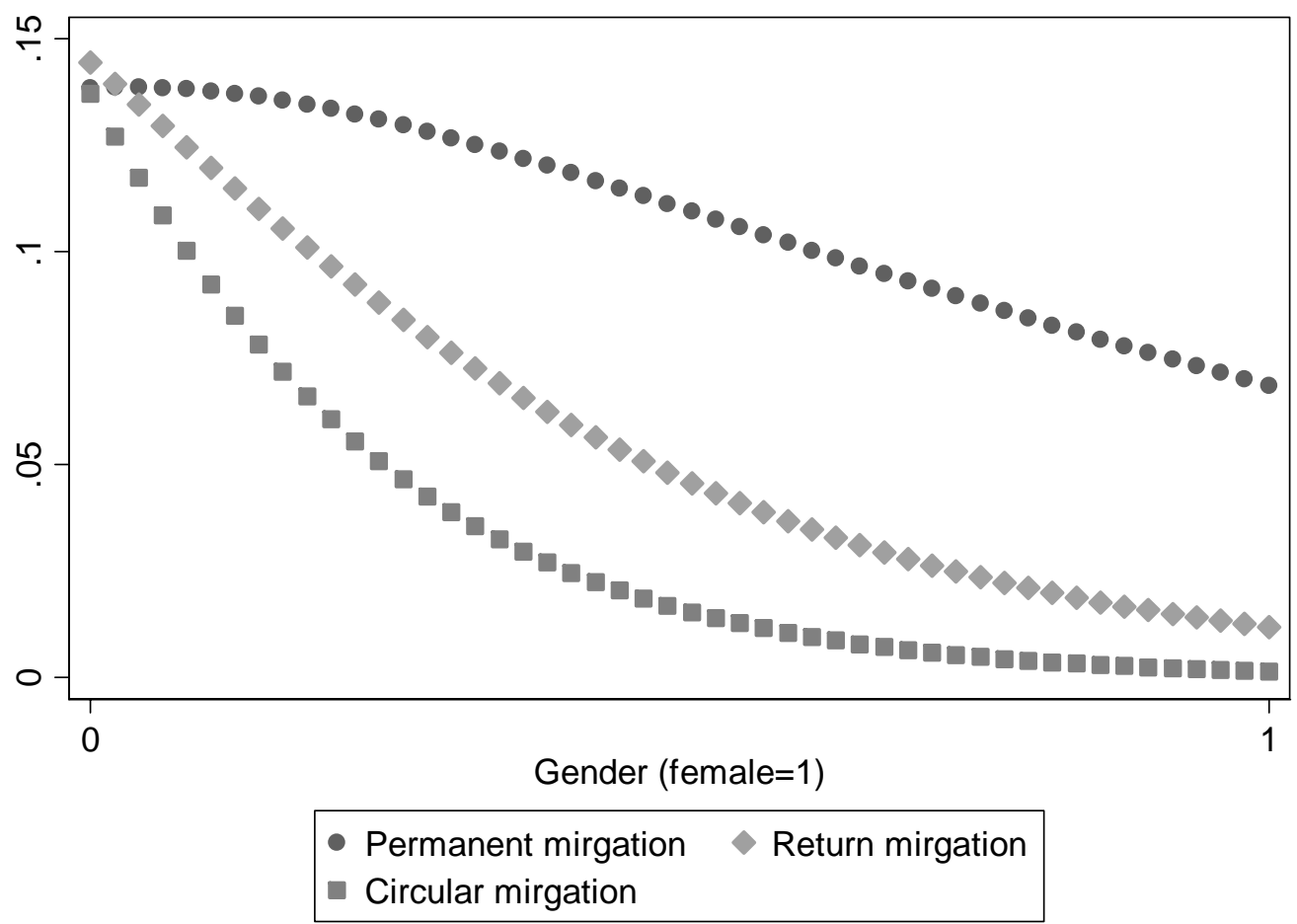

Note: Predicted probabilities are computed using the mlogit estimation results presented in Table 2.

Figure 2: Predicted probabilities of migration form by age

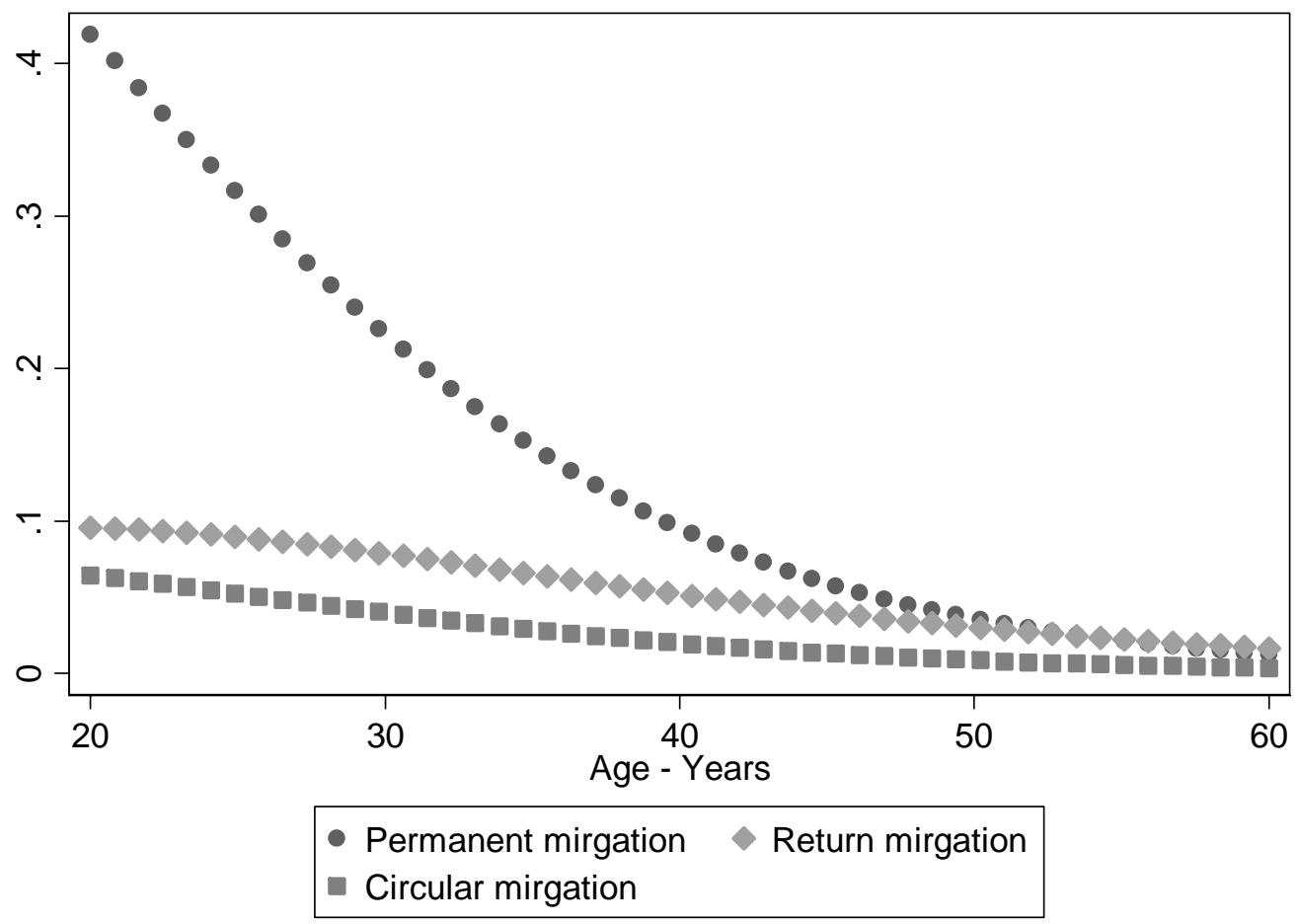

Note: Predicted probabilities are computed using the mlogit estimation results presented in Table 2. 